\title{
Institutional Environment, Community Government, and Corporate Governance: Understanding China's Township-Village Enterprises
}

Jiahua Che

University of Notre Dame

Yingyi Qian

Stanford University

We study China's township-village enterprises (TVEs) from an organizational perspective with a focus on governance. Unlike most previous studies, we interpret the firm boundaries of TVEs at the community level rather than the enterprise tevel. From this perspective, we analyze the central role that community governments play in TVE governance as an organizational response to the imperfect institutional environment of both state and market Specifically we show that the community government's involvement in TVEs helps overcome the problems of state predation and underfinancing of private enterprises. We also explain why TVE governance leads to harder budget constraints than state-owned enterprises.

\section{Introduction}

The remarkable development of the nonstate sector has changed the landscape of China's industries (Table 1). In 1978, 78\% of national industrial output came from state-owned enterprises (SOEs); by 1993 that percentage had sunk to a $43 \%$ level, with nonstate enterprises providing $57 \%$ of total production. The most dynamic segment in the nonstate sector is rural enterprises (xiangzhen qiye), which accounted for $36 \%$ of the national industrial output in 1993, up from $9 \%$ in 1978. Within the rural sector, the township and village enterprises (xiangcun qiye), or TVEs, account for about three-quarters of rural industrial output, or more than one quarter of the national total.'

The authors are grateful to Masahiko Aoki, Pranab Bardhan, Erik Berglof, Ronald McKinnon, Paul Milgrom, Ramon Myers, Dwight Perkins, Thomas Rawski, William Simon, Yijiang Wang, Barry Weingast, two referees, and especially Pablo Spiller for helpful discussions and comments. This article was written when the second author was a National Fellow at the Hoover Institution at Stanford. Financial support from the Center for Economic Policy Research (CEPR) at Stanford is gratefully acknowledged.

1. Chinese statistics classify rural enterprises into four categories in terms of ownership: townships (xiangban), villages (cunban), groups of households (lianhu, including cooperatives and partnerships), and individual households (geti, i.e., a sole proprietorship employing less than eight employees). TVEs refer to the first two categories. Although each village is under the jurisdiction of a township, a village enterprise differs from a township enterprise; the former is run by the village govemment and the latter by the township government. In $1992,39 \%$ of rural industrial

(C) 1998 Oxford University Press 
Table 1 China: Shares of Industrial Output Value by Ownership (19781993)

\begin{tabular}{|c|c|c|c|}
\hline & 1978 & 1993 & $\begin{array}{c}\text { Changes } \\
\text { between } \\
1978 \text { and } \\
1993\end{array}$ \\
\hline State-owned enterprises (SOEs) & $77.63 \%$ & $43.13 \%$ & $-34.50 \%$ \\
\hline Nonstate-owned enterprises & $22.37 \%$ & $56.87 \%$ & $34.50 \%$ \\
\hline $\begin{array}{l}\text { Urban nonstate enterprises } \\
\text { a. Urban collectives } \\
\text { b Urban Individuals }\end{array}$ & $\begin{array}{r}13.28 \% \\
13.28 \% \\
0.00 \%\end{array}$ & $\begin{array}{r}1042 \% \\
9.72 \% \\
0.70 \%\end{array}$ & $\begin{array}{r}-2.86 \% \\
-3.56 \% \\
0.70 \%\end{array}$ \\
\hline $\begin{array}{l}\text { Rural enterprises } \\
\text { a. Township enterprises } \\
\text { b. Village enterprises } \\
\text { c Household groups } \\
\text { d. Indmindual households }\end{array}$ & $\begin{array}{l}909 \% \\
505 \% \\
404 \% \\
0.00 \% \\
0.00 \%\end{array}$ & $\begin{array}{r}36.29 \% \\
14.23 \% \\
12.25 \% \\
2.21 \% \\
760 \%\end{array}$ & $\begin{array}{r}2720 \% \\
918 \% \\
8.21 \% \\
2.21 \% \\
7.60 \%\end{array}$ \\
\hline $\begin{array}{l}\text { Others (large private, foreign, } \\
\text { joint ventures, stock } \\
\text { companies, etc) }\end{array}$ & $000 \%$ & $10.16 \%$ & $10.16 \%$ \\
\hline Total & $100 \%$ & $100 \%$ & $0 \%$ \\
\hline
\end{tabular}

What are TVEs? A TVE refers to a (typically industrial) business unit that belongs to all residents of a rural community where it is also usually located. A rural community can be either a township (about 3,500 households) or a village (about 200 households), with each community usually having a number of such enterprises. TVEs are neither SOEs (which are national public firms owned by the central government), cooperatives (such as labor-managed firms in Yugoslavia and workers cooperatives in Mondragon, Spain), nor private enterprises. We will argue that TVEs are best characterized as community enterprises with a governance structure in which the community government has control. The central focus of our article is what roles the community government plays in the corporate governance of TVEs and how these roles are shaped by the imperfect institutional environments of both state and market.

We start our analysis by viewing the collection of TVEs in a community as one firm, because most strategic control rights are exercised by the community governments rather than the enterprises themselves, according to extensive evidence in legal regulation and from practice. From this perspective, it is natural to regard community residents as major beneficiaries of the firm, community government as the board of directors and management at the headquarters of the firm, and individual TVEs as divisions, branches, or subsidiaries within the

output originated from enterprises run by townships, $34 \%$ by villages, $7 \%$ by groups of households, and $20 \%$ by individual households (Ministry of Agriculture, China, 1992a:17). 
firm. Such a three-tier structure resembles that of conventional, publicly held multidivisional corporations in the West.

This perspective allows us to establish a theoretical framework that focuses on the role of the community government in TVE governance and the institutional environments that shape these roles. We characterize the community government with two basic features concerning its scope of authority. First, the community government has full autonomy over both government and business activities within its community; and second, as the lowest level of government in the rural area, the community government's power is limited in dealing with state financial institutions such as state banks. We analyze how the community government's involvement in TVE governance interacts with the imperfect state and market institutions in the processes of transition from a planned to a market economy and development from an agrarian to an industrial economy. We address three major issues in this analysis.

First, because of a lack of institutions that protect property rights, private enterprises are vulnerable to state predation, which distorts private investment incentives. We argue that, because community governments also provide productive local public goods, which increase future revenues for higher levels of government, community government-controlled TVEs are better at preventing higher government predation and thus bring about fewer incentive distortions. The cost of TVEs is the lower incentives provided for managers.

Second, start-up private enterprises also have difficulty in raising capital to finance their investments in imperfect capital markets due to well-known problems such as moral hazard and adverse selection. We explain that, by involving the community government as an intermediary, the governance of TVEs helps facilitate financial contracting because of the community government's better endowed physical capital (which can be used as equity investment) and human capital (which can be used for monitoring managers). However, the benefits of TVEs are counterbalanced by two major costs of TVEs-the government's monitoring cost and the cost of preventing the government from diverting funds for private benefits.

Finally, there is an intriguing question as to why TVEs and SOEs, which are both government controlled, might differ. One fundamental difference is the degree of softness of budget constraints these enterprises face. SOEs suffer from a soft budget constraint problem (Kornai, 1980). Since government controls both SOEs and banks, it can order a bank to refinance projects, if it seems necessary. In the case of TVEs, however, although the community government controls enterprises, it does not control banks. Thus the community government can only influence or bargain with a bank, but it cannot order it to provide refinancing. This separation of control over enterprises and banks may allow banks to refuse refinancing when the benefits of refinancing are small (Dewatripont and Maskin, 1995). In this way, community governments and TVEs face harder budget constraints.

Our analysis furthers the existing literature on TVEs. Although most studies of TVEs acknowledge some of the positive roles community governments play, they do not substantiate how such roles come about in the particular institutional 
environment. For example, community government is considered to be capable of economizing transaction costs for TVEs (Nee, 1992), providing critical inputs (such as credit) for TVEs (Chang and Wang, 1994), and protecting TVEs in adverse political circumstance ( $\mathrm{Li}, 1996)$. However, it remains unclear why the community government has such capabilities. Without understanding these mechanisms, it also becomes difficult for analysts to assess the limits of the community government's roles. In this article we intend to fill this gap by sorting out the mechanisms underlying such roles. In addition, we address some crucial differences between TVEs and SOEs.

The article is organized as follows. Section 2 presents empirical evidence on the governance of TVEs and the role of community government in TVEs. Section 3 provides a theoretical framework by characterizing TVE governance, the institutional environment in which TVEs operate, and the community govemment which plays a central role in that governance. Sections 4 and 5 analyze the costs and benefits of TVE governance compared with those of startup private enterprises in the contexts of security of property rights and financing of investments, respectively. Section 6 explains why TVEs have harder budget constraints than SOEs. Section 7 concludes with two general lessons drawn from the TVE experience. The Appendix describes the evolutionary process of TVEs.

\section{Empirical Evidence on the Governance of TVEs and the Role of Community Government}

What makes TVEs special is a governance structure in which the community government plays an active role. In this section we provide empirical evidence concerning TVE governance and the role of community government from the points of view of both legal regulation and actual practice.

\subsection{Legal Regulation on the Governance of TVEs}

The central government has issued nationwide regulations regarding TVEs that are intended to delineate distributions of control rights and benefits among township and village enterprises, community residents, and community govermments. One of the most comprehensive legal regulations to date is the Regulation on Township and Village Collective Enterprises of the People's Republic of China, issued in 1990 (Ministry of Agriculture, China, 1990). This regulation spells out, among other things, ownership rights of TVE's assets, allocation of control rights, and rules concerning distribution of after-tax profits.

First, the regulation specifies the nature of community ownership of the assets of TVEs as follows: "Assets (of a TVE) are owned collectively by the whole of rural residents of the township or village who run the enterprise; the ownership rights over the enterprise assets shall be exercised by the rural residents' meeting (or congress) or a collective economic organization that represents the whole of rural residents of the township or village. The ownership rights of the enterprise assets will not change when the enterprise is under a managerial contract responsibility system, leasing, or joint operations with enterprises of other types of ownership" (Article 18, Chapter 3, Ministry of Agriculture, China, 1990:81). Therefore TVE assets legally belong to the 
residents of the township or village, not to enterprise employees or residents outside the community.

Second, the regulation specifies the allocation of control rights: "The owner of a TVE, according to the law, determines the direction and formats of its business operations, selects managers or determines the method of such selection, determines the specific distribution ratios of after-tax profits between the owner and the enterprise, and has the rights over the enterprise concerning its spinoff, merger, relocation, stop-operation, close-down, application for bankruptcy, etc." (Article 19, Chapter 3, Ministry of Agriculture, China, 1990:84). Thus the owner has the control rights. While the owner can delegate such rights to an agency, according to the previous paragraph, the agency must represent the whole of the community rather than a particular enterprise. Typically this agency is called the "Economic Commission" or the "General Corporation for Development" of the community government.

Third, the regulation also stipulates rules for the distribution of after-tax profits of TVEs: "The part retained by the enterprise should be no less than $60 \%$ of the total and should be arranged under the enterprise's autonomous decision. The retained after-tax profits for the enterprise should be mainly used for the increase of the funds for production development in technological transformation and expansion of reproduction, and also for the appropriate increase of welfare funds and bonus funds." And "the part remitted to the owner of the enterprise should be used mainly for the support of construction of agricultural infrastructures, agriculture technology services, rural public welfare, renewal and transformation of enterprises, or development of new enterprises" (Article 32, Chapter 5, Ministry of Agriculture, China, 1990:137). As is evident, this regulation restricts the use of revenue by community residents and government to essentially two purposes: reinvestment and local public goods.

\subsection{The Role of Community Government in TVEs in Practice}

Below we present empirical evidence from field studies about actual practice concerning the role of community government in exercising control rights over TVEs. We use two studies, one came from the World Bank (Byrd and Lin, 1990) and another from Oi (1994). The World Bank study was conducted in the late 1980 s in collaboration with the Chinese Academy of Social Sciences. It covered four counties in China (Jieshou of Anhui province, Nanhai of Guangdong province, Shangrao of Jiangxi province, and Wuxi of Jiangsu province). Oi's study took place mainly in Zouping county of Shandong province in the early 1990s. Both studies found that, although most TVEs enjoy a considerable degree of enterprise autonomy, this autonomy is largely restricted to daily operation decisions or management. In particular, the community government makes three types of strategic decisions in the areas of (i) investment and finance, (ii) selection of managers, and (iii) the use of after-tax profits for public expenditure, as detailed below. ${ }^{2}$

2. These conclusions are confimed by other studies from Chinese sources; see, for example, Ma, Wang, and Lin (1994), which contains 32 case studies of TVEs in three provinces of Shandong. Jiangsu, and Gansu. 
2.2.1 Investment and Finance. Both studies found that most projects set up by TVEs have to be approved by community governments. The community governments initiate intemal fund-raising, either from collective accumulation or from individual contributions. The community governments are also pivotal in securing loans from either the Agriculture Bank of China (ABC) or Rural Credit Cooperatives (RCCs), two major external sources of financing. The field studies show that the community government provides several levels of service. First, when TVE loans come from the county branches of the ABC, the township and village govemments initiate the process of bargaining and borrowing. Second, township and village enterprises can use the community assets (which could be assets of other enterprises in the same community) as equity or collateral. Third, township and village governments may provide loan guarantees. In such a case, community governments assume the final responsibility for repayment if the borrowing TVE cannot pay it back. Community governments manage to repay bad loans, through their fiscal budgets, or from after-tax profit remittances, or by arranging for other TVEs to repay them. ${ }^{3}$ Without the community government's involvement, it is usually very difficult, if not impossible, for TVEs to obtain loans directly from either the ABC or RCCs.

2.2.2 Selection and Rewarding of TVE Managers. Managers are often employed under some form of managerial contract that specifies tenure and compensation schemes. However, the community government represents the owner of TVEs in negotiating the form of contracts (e.g., fixed-wage, profit-sharing, or leasing contracts), and signs the contract with the managers. ${ }^{4}$

2.2.3 Use of After-Tax Profits for Public Expenditure. The community government has direct control over two parts of after-tax profits from TVEs. The first part is that portion remitted directly to the community government and known as "management fees." The second part is the profits retained by TVEs but earmarked for public expenditures. The community government decides on the use of those funds for supporting agriculture and providing community welfare, that is, for schools, roads, health care, pensions, etc. In addition, the community government also has significant influence on the remaining aftertax profits, which are used for reinvestment through, for example, controlling investment as described above. At the national level, in 1985 , about $46 \%$ of TVEs' after-tax profits was reinvested and $49 \%$ was used for local public ex-

3. Byrd (1990:203) observed: "The community government's ability to absort risk by varying its public expenditure may be limited, but it can spread risk across its enterprises to increase the flexibility and ability to absorb losses of any one firm." Oi (1994) also reported: "The debts of a village or township are the responsibility of the collective. Interviews reveal that in a number of localities when a collective enterprise fails and defaults in its loans, the debt is paid off by the other enterprises regardless of the specifics of the contracting system."

4. According to Oi (1994), "Those who run the enterprise are dependent on the local government officials who appoint them. There is competitive bidding to win contracts, but local officials ultimately decide who will be given the contract." 
penditure, including $12 \%$ for welfare. In 1992, 59\% of TVEs' after-tax profits was reinvested and $40 \%$ was used for local public expenditure, including $9 \%$ used for welfare (A Statistical Survey of China, 1992:67; A Statistical Survey of China, 1993:67).

\section{A Theoretical Framework}

In this section we establish a theoretical framework upon which the rest of the analysis will be built. We first characterize the governance of TVEs by drawing a parallel with the governance of a conventional, multidivisional corporation in the West. We then specify the institutional environments of the state and market in which TVEs are operating. Finally, we delineate two basic features of the community government which are essential in our subsequent analysis of the central roles of the community government in the governance of TVEs.

\subsection{Characteristics of the Governance of TVEs}

As the above empirical evidence demonstrates, the governance of TVEs, from both legal and practical points of view, has the following three properties: (i) all community enterprises within one community are owned collectively by the residents of that community; (ii) the decisions of managers of these enterprises are restricted mostly to daily operations; and (iii) the community government exercises strategic control rights over these enterprises on behalf of the community residents.

Therefore we interpret the collection of all community enterprises within a particular community as the bottom tier of a three-tier structure, in which the middle tier is the community government which exercises strategic controls over these enterprises and the top tier consists of the residents. With this perspective, we view the entire three-tier structure as a firm, which can appropriately be called a "community corporation."

This perspective provides valuable insights into TVEs. ${ }^{5}$ Indeed the three-tier structure of TVEs resembles a publicly held, multidivisional corporation or a holding company in the West (Byrd, 1990; Oi, 1992) ${ }^{6}$ As is well known, a publicly held corporation has many owners who grant control rights to the board of directors and the top executives of the firm. Inside a multidivisional corporation, headquarters centralizes strategic decisions involving finance, investment, and selection and evaluation of managers, while delegating daily management

5. Viewing the boundaries of the firm at the community level also helps clarify some of the confusion in the literature which typically interprets the boundaries of the firm for TVEs at the enterprise level. First, the disagreement over whether TVEs have clearly specified property rights [e.g., Weitzman and Xu (1994) versus Naughton (1994)] becomes less pronounced and will be probed from a new perspective. Rather the relevant question is the efficiency of the existing allocation of control rights (see Grossman and Hart, 1986; Hart and Moore, 1990). Second, different views on the hardness of budget constraints of TVEs [e.g., Whiting (1995) versus McKinnon (1994)] can also be reconciled. Cross-subsidization among TVEs within a community can coexist with the hard budget constraints of the community to which these TVEs belong.

6. Most TVEs are legal persons, while divisions in a corporation are not. In this respect, the structure of TVEs is more like a holding company. 
to divisions (Chandler, 1966; Williamson, 1975). In the parallel situation of TVEs, community residents are the major beneficiaries of the firm, the community government serves as both the board of directors and management at the firm's headquarters, and individual TVEs are separate divisions, branches, or subsidiaries within the firm. ${ }^{7}$

As in corporations, the three-tier structure of TVEs entails agency costs, such as those associated with the separation of beneficiaries and control, and those associated with the managers of community enterprises. These agency costs may be exacerbated further in TVEs for the following reasons. First, it is the community government rather than business managers that exercises strategic control of the firm, and this setup may give rise to (additional) political costs. Second, the rights of community residents as beneficiaries of TVEs are restricted. Community residents generally cannot sell their implicit "shares" to other people, and they do not have the formal right to elect and dismiss the community government's officials and to vote on strategic decisions.

Considering these agency costs, it would appear that private enterprises, which have a much simpler organizational structure and are less prone to the internal agency problem, should have advantages over TVEs. ${ }^{8}$ In order to explain the success of TVEs, we need to investigate the potential benefits of their three-tier structure. The key to understanding TVEs' potential benefits lies in the roles of the community government and the institutional environment that shapes these roles.

\subsection{The Imperfect Institutional Environment}

The roles of the community government in TVEs are shaped by the institutional environment in which they operate. We take the view that during economic development and transitions to market both state and market institutions are imperfect and will take time to evolve. We consider three types of imperfections and their potential adverse consequences on economic development and transition to markets.

First, state institutions are imperfect, particularly due to a lack of the rule of law and institutions that constrain the state from arbitrary revenue expropriation?

7. Because the rights of community residents are restricted, community residents are more appropriately referred to as beneficiaries, rather than owners, of TVEs (Chang and Wang, 1994).

8. Two special mechanisms of TVEs may have helped in part to contain some of the agency costs. First, TVEs' after-tax profits must be used mainly for the purpose of reinvestment and local public expenditure. Because the heads of townships and villages are appointed and dismissed by the county and township governments, respectively, these restrictions can be enforced to some extent as the residents can voice their concerns to higher governments, although they cannot vote. Second, a township, especially a village, is a small community, and most township and village government officials and TVE managers are residents of the same community where TVE investments are located. Because community government officials and TVE managers interact with residents frequently (they usually have extensive family ties in the community), their activities can be better monitored by residents, which helps reputation mechanisms work.

9. North (1990) discusses the issue in the historical perspective. The lack of credible commitment by the state under central planning, which induces the so-called ratchet effect, was a major topic in the literature of comparative systems (see Komai, 1980). Litwack (1991) links the lack of credible commitment to the lack of rule of law. 
In China there is no independent judiciary system: the parliament, executive branch, and courts are all under the control of the Party. Therefore there is no law- or institution-based commitment to bind the state to a fixed schedule of taxes; the state has the ultimate authority for determining taxes and can arbitrarily set and change tax schemes for enterprises and lower level governments. This creates serious commitment problems which can distort investment incentives.

Second, the capital market is also imperfect, due to the well-known adverse selection and moral hazard problems. As an investor may not be sure whether an entrepreneur's idea is good and the investor may also be unable to force the entrepreneur to take an appropriate action, entrepreneurs find it difficult to raise capital, and many investment opportunities pass by without financing. These problems are even more profound in developing and transition economies such as China because start-up entrepreneurs do not generally have much wealth.

Third, China lacks a competitive banking system. Until recently, all banks in China were state owned. The central government controls SOEs, state banks, and the central bank. Clearly the central government can order a state bank to provide funds to a state enterprise and to order the central bank to print money whenever it appears necessary. ${ }^{10}$ The combination of state ownership of industrial firms with control over financial institutions may cause another serious commitment problem, that is, the state often has difficulty refusing to bail out inefficient SOEs once investments are sunk (Dewatripont and Maskin, 1995). Anticipating relaxed financial discipline, SOE managers may then make irresponsible business decisions, which can lead to inefficiencies. This is known as the "soft budget constraint" problem (Kornai, 1980).

It is in this imperfect institutional environment that we see the potential benefits of involving the community government in TVE governance. These benefits come about as a result of some of the particular features of community governments in rural China.

\subsection{The Basic Features of the Community Government}

The governmental hierarchy in China has six layers: central, provincial, prefecture, county, township, and village (a municipality is assigned a level of provincial, prefecture, or county depending on size). The community governments of townships and villages (formerly communes and brigades) have the following two basic features, which, as we will show, underscore the crucial differences between TVEs and private enterprises on the one hand, and between TVEs and SOEs on the other.

The first basic feature concems the community government's scope of authorities:

(G1) The community government has full autonomy over both government and business activities within its community.

10. Under decentralization, regional governments at provincial, prefecture, and county levels also have control over state bank branches and SOEs in their regions, thus these governments can also order a state bank branch to provide funds to a state enterprise in their regions. 
China's economy was more decentralized than most other centrally planned economies even before reforms began. Since 1980, reforms have focused on further decentralization of the government (Qian and Weingast, 1996; Qian and $\mathrm{Xu}, 1993$; Wong, 1992). As a result, community governments have obtained full autonomy over activities such as community development and welfare.

As the governing body, the community government carries out a wide variety of government activities, ranging from maintaining social order to providing basic living conditions (e.g., sanitary facilities), from building local infrastructure (e.g., roads) to implementing family planning policy. In addition to these traditional government functions, the community governments in China are engaged in organizing local business as well. This central involvement in business activities originated in the commune system, when community govemments were responsible for agricultural production. Later, it evolved into the management of industrial activities (see Appendix).

This comprehensive scope of the community government's authority in China distinguishes it from local governments in many other countries, whose authority is usually confined to government activities. On the other hand, it also distinguishes the community government-run business from businesses operated by private entrepreneurs, because the latter do not have responsibility for government activities.

The second basic feature concems the limits of the community government's authorities:

(G2) As the lowest level of government in rural areas, the community government's power is limited in dealing with state financial institutions (such as state banks).

In China, the rural sector has not been incorporated into the state industrial system (Byrd and Lin, 1990; Ma et al., 1994); and furthermore, the authority of the community government has not been extended to the state banking system. The ABC and RCCs are the two major potential sources of external finance for both TVEs and private enterprises. Although the community government controls TVEs, it does not control these state banks. Therefore the community government cannot order a bank to provide funds; instead, it has to negotiate the terms of financing with these banks.

We will argue in the next three sections that these two basic features play important roles for TVEs in dealing with the unsympathetic environment described above. In particular, the community government's first basic feature (G1) helps TVEs reduce state predation and raise capital in an imperfect capital market. Both factors give TVEs advantages relative to private enterprises. Furthermore, the second basic feature (G2) causes harder budget constraints for TVEs than for SOEs.

\section{Security of Property Rights}

Evidence shows that property rights are better secured in TVEs than in private enterprises. First, the state's regulations have been less hostile to TVEs 
than to private enterprises. Collective enterprises such as TVEs always have been legally allowed to operate. As early as the mid-1970s, during the wave of "agriculture mechanization," many rural areas began to launch communebrigade enterprises (the predecessor of TVEs) despite the fact that they were regarded as the "tail of capitalism" and faced all kinds of attacks (Byrd and Lin, 1990:10). Starting in 1978, the central government declared that communebrigade enterprises should strive for greater development, and it encouraged provincial, city, and county governments to adopt "a policy of allowing tax breaks or tax exemptions for commune and brigade enterprises in the light of their situation." " In comparison, the central government did not allow private enterprises to operate until 1981 and limited their hiring to no more than eight employees per enterprise (a restriction that was removed in 1984).

Second, security of private property rights is not guaranteed even if there exist legislation or regulations exist on paper. The state has attacked private enterprises during each of the general political crackdowns, which includes the "anti-spiritual pollution campaign" of 1983, the "anti-bourgeois liberalization campaign" of 1987, and most recently, after the Tiananmen incident of 1989. In August 1989 the state attacked "individual and private entrepreneurs who use illegal methods to seek huge profits and thereby create great social disparity and contribute to discontent among the public" and launched a series of investigations into the taxation of individual and private firms. ${ }^{12}$ In comparison, no such attack on TVEs was reported during this same time period.

Facing such uncertainties, private enterprises have been concerned-understandably - about the adverse consequences of political crackdowns and they have reacted by withholding investment or seeking protection. Based on her interviews in Wenzhou in 1991, Whiting (1995) reports that private entrepreneurs were very worried about possible "policy changes" toward private enterprises and the great "psychological pressure" felt by private enterprise owners. A study by the Economic Policy Research Center of the Ministry of Agriculture reports significant reduction of investment in private enterprises from 1989 to 1990 because of these perceived policy changes. According to this study, the registered capital of private enterprises in Wenzhou declined by $5 \%$ in 1989 ; in several cases, private entrepreneurs liquidated their assets and took them abroad. ${ }^{13}$ Some private enterprises sought protection by converting their firms into TVEs. The authors' interviews in Wenzhou in 1992 and 1994 found that several private enterprises were converted into TVEs in the wake of the retrenchment between 1989 and 1991 .

Still the question remains: Why are the property rights of TVEs better secured than those of private enterprises? We will argue that the first basic feature of the community government (G1) provides an advantage to TVEs when there is a lack of credible commitment from the state. The idea is that, when the com-

11. "Resolution on Several Questions about Speeding Up Agricultural Development," December 1978, as quoted by Byrd and Lin (1990).

12. State Council document, August 30, 1989, as quoted by Whiting (1995:109, footnote 100).

13. As quoted by Whiting (1995:111). 
munity government engages in both providing productive local public goods and controlling TVEs, it becomes more useful than private entrepreneurs to the higher government. At equilibrium, the higher level government may optimally prey less on TVEs than on private enterprises, and the community government may be less worried about revenue confiscation by the higher government. As a result, more efficient projects may be implemented.

To elaborate this idea, we consider a two-period model with three playersan entrepreneur, a community government, and a county government. The objective of the county government is maximization of the sum of the twoperiod revenues collected. In order to capture the institutional imperfections of the state, we assume that nothing binds the county government from arbitrarily taking away observable revenues from either private enterprises or community governments. This implies that no revenue-based contracts are feasible.

In each period a project generates some observable revenues as well as some unobservable private benefits. There are two projects, referred to as project 1 and project 2 . In the first period, for any given effort level of the entrepreneur, project 2 yields higher sums of the observable revenue and the unobservable private benefit than project 1 . However, the unobservable private benefit from project 1 is higher than from project 2 . One could think that project 1 involves more revenue hiding than project 2 , at the cost of a lesser amount of total returns (such as choosing projects whose profits can be easily concealed). In the second period, the technologies of generating the observable revenues and unobservable benefits are the same between project 1 and project 2 , with both dependent on effective government services described below. Overall, project 2 is more efficient (in terms of the net sums of the observable revenues and the unobservable private benefits in two periods) than project 1.

The community government provides productive local public goods, which help increase both project revenues and the private benefits of projects in the second period. For example, a stable social environment reduces business uncertainties; infrastructure investment helps reduce the costs of production, and basic living conditions improve workers' productivity. However, because of the free-rider's problem, entrepreneurs individually have no incentives to provide an efficient level of local public goods. On the other hand, because these services increase observable revenues in the second period, the county government has an interest in seeing that these services are adequate. Whether or not the community government provides such services, however, depends on its incentives. We assume that effective government service depends on both the level of effort (low or high) from the community government (with some private cost) and the revenue that remains with it from the first period. One can think of that portion of the revenue as the working budget for the community government in the second period. To capture the complementarity between the community government's budget and efforts, we also assume that the marginal productivity of the community government's budget is high (or low) if the community government exerts high (or low) effort.

In the case of private enterprises, an entrepreneur chooses the project type and receives unobservable private benefits. Because private benefits accrue to 
the entrepreneur and the second period's observable revenues are always taken away by the county government, the community government has no share in the second period payoffs, either observable or unobservable. Consequently the community government will provide low efforts in providing its services. Thus, according to our assumption of low marginal productivity with a community government's low effort, the county government will provide only minimum working budget for the community government in the second period. Anticipating this, the entrepreneur maximizes the first period private benefits by choosing the less efficient project 1 . In the end, because project 1 entails costly revenue hiding, and because there are few effective community government services, the total amount of observable revenues collected by the county government is also small. This is clearly an inefficient equilibrium, and is a direct result of the lack of credible commitment on the part of the county government.

Can TVEs do better? With TVEs, it is the community government that selects the project type (as is evident in Section 2) and receives unobservable private benefits. Because all the private benefits accrue to the community govemment, it now has an incentive to exert high efforts in providing government services. As a result, the marginal productivity of its working budget becomes high. Instead of leaving a minimum amount of observable revenues to the community government, the county government may now appear more "generous" and leave a larger amount for the community government's working budget, because this may increase the observable revenues in the second period. This amounts to "keeping hens for more eggs," an old Chinese saying. As long as the higher second period observable revenues from the increased productivity of the community government's budget outweighs the costs of sacrificing the first period's revenue, the county government will provide, out of its own interest, a larger budget to the community govemment.

Moreover, realizing that a larger amount of first period observable revenues will be left to its discretion, the community government may have an incentive to choose project 2 over project 1 . For although the community govemment's first period private benefits are reduced, the first period observable revenues increase, which may raise its working budget for the second period. This in turn may enhance its second period private benefits.

Therefore, it is possible that, with TVEs, the more efficient project 2 will be chosen, a larger amount of revenue will be left with the community government, more community government services are provided, and more revenues are also collected by the county government. At equilibrium, the county government will (optimally) prey less on TVEs than on private enterprises. Evidently the main drawback of TVEs is the low incentives provided to the entrepreneur, who now becomes the manager of TVEs and is deprived of receiving unobservable private benefits.

In essence, TVE govemance may reduce the efficiency loss resulting from state predation because the community government integrates government and business activities. Two effects can be identified. The first is the incentive effect. Controlling business activities allows the community government to receive private benefits, so that it will benefit from the fruits of exerting high efforts 
in conducting government activities when contracts are not enforceable. Then the county government is willing to leave more revenues with the community government. The second effect is the less revenue hiding effect. When the community government integrates the two activities, it partially internalizes the costs of inefficient project choices. Hence, given the incentives provided by the ownership, the community government may choose more efficient projects, and the county government appears even more "generous" toward TVEs than to private enterprises. In summary, the community government's involvement in TVEs can be interpreted as an organizational response to the commitment problem under imperfect state institutions.

These theoretical results are consistent with the evidence presented at the beginning of this section. They are also consistent with the evidence presented in Section 2 that a large portion of after-tax revenue of TVEs is actually used for public expenditure. In addition, in their econometric work using provincial data between 1986 and 1993, Jin and Qian (1997) found that the share of TVEs in the rural nonfarm economy increases both the state and community shares of rural income (and reduces the household share), after controlling for the level of per capita income. This evidence not only supports our above results, but also shows that it is in the interests of both the state and community governments to have more TVEs than private enterprises.

\section{Financing of Investment}

Evidence also shows that TVEs receive larger loans, invest in larger-scale projects, and engage in more capital-intensive industries than do private enterprises. In a 1989 sample from Zhejiang and Sichuan provinces, the median size of loans extended to township enterprises, village enterprises, and private enterprises was 123,700 yuan, 43,000 yuan, and 18,000 yuan, respectively, and the mean size of such loans was 299,649 yuan, 218,873 yuan, and 58,996 yuan, respectively. The capital:labor ratio was 11,323 yuan per township enterprise, 7,458 yuan per village enterprise, and 6,447 yuan per private enterprise. ${ }^{14}$ At the national level, about one-half of TVE industrial output comes from heavy industries, which are generally more capital-intensive industries. For example, in $1985,49.9 \%$ of industrial output came from heavy industries (of which $78.5 \%$ was from manufacturing, $13.6 \%$ from material processing, and $15.4 \%$ from mining), and in $1991,45.6 \%$ of industrial output came from heavy industries (of which $66.4 \%$ came from manufacturing, $21.0 \%$ from material processing, and 12.6\% from mining) (Ministry of Agriculture, China, 1992b:50).

What explains the different pattern of financing investments between TVEs and private enterprises? It is not hard to understand that start-up private enterprises entail high agency costs in terms of borrowing funds for investment because of the problems of adverse selection and moral hazard as well as their

14. Table 2, Table 28, and Table 6 in Zhang and Ronnas (1993). The data on loan size are for loans at the enterprise level. At the community level, the difference is even more striking, because on average each township has 8.2 township enterprises and each village has 1.4 village enterprises. 
limited wealth (Holmstrom, 1995). In the case of TVEs, the first basic feature of community government (G1) helps to explain the advantage of TVEs in financing investment.

As indicated by the evidence in Section 3, when a TVE needs funds for its investment, the community government borrows a loan from a bank and provides the funds to the entrepreneur, now the TVE manager. Because community governments have been engaged in both government and business activities for some time, they already had substantial physical and financial resources at the beginning of economic reform. For example, in 1980, rural per capita household savings deposits were only 14.7 yuan (Almanac of China's Finance and Banking, 1993). In contrast, rural per capita collective fixed assets were 126.94 yuan (Ministry of Agriculture, China, 1986). In addition, as we demonstrated above, the integration of these two activities provides a safeguard for the autonomous control of these assets. As a result, the community government can utilize these assets to act as an intermediary for financing TVEs in an imperfect capital market.

The involvement of the community government, however, adds at least two types of agency costs. First, separating management and control entails costly government monitoring. Second, the government may have incentives to divert funds away from investment as well (to serve its own political agenda for example). Therefore TVE governance has a trade-off between different types of agency costs in intermediating investment finance.

To formalize these ideas, we again consider a model with three players-an entrepreneur, a community government, and a state bank, which has capital. The cost of capital is $r$, which represents the safe rate of return. The entrepreneur has an idea about an investment project that requires one unit of capital; however, he has very limited wealth (less than one unit of capital). If the entrepreneur does not divert the investment funds he borrows from the bank, the project generates the safe return $a$, which is higher than $r$. But the entrepreneur may divert some funds for certain private benefits $b$. If he does that, the project becomes risky: It succeeds and generates the return $a$ with some probability $\pi$ less than 1; otherwise the project fails and yields zero return. We assume that the expected return plus the private benefits will be lower than the safe rate of return (i.e., $a \pi+b<r$ ), therefore the bank will not finance the project if the entrepreneur diverts the funds. We assume now that loan contracts are feasible, but there is a usual limited liability constraint on the part of the entrepreneur.

When the entrepreneur has no wealth to invest as equity, he has a strong incentive to divert the funds because he is the sole claimant of the private benefits, whereas he is entitled to (at most) part of the project's returns. Nevertheless, when the entrepreneur does have some wealth to invest, his propensity to divert investment funds for private benefits will depend on the amount of his own wealth that is invested in the project. A higher amount of his own investment increases his stake in the project and therefore helps internalize the costs of diverting investment funds. Consequently there will be a threshold of wealth for an individual entrepreneur such that the bank is (not) willing to finance 
his investment if his wealth is greater (less) than the threshold. ${ }^{15}$ Because an entrepreneur's wealth is generally low at the start of reform and development, his investment usually cannot be financed.

Under TVE governance, the community government borrows from the bank and provides the funds to the entrepreneur, now the manager of a TVE. To capture the possible advantages of the TVE, we assume that community wealth is larger than private wealth, and that, with some monitoring cost $c$, the government can ensure that no funds will be diverted by the manager. However, the community government itself is also subject to incentive problems. For simplicity, we assume that the government can divert funds only if it is engaged in monitoring managers. ${ }^{16}$ When the community government monitors the manager but diverts the funds for itself, it receives the same amount of private benefits and brings on the same project riskiness as when funds are diverted by the entrepreneur.

Clearly both the community government's stake in the project and the return from the investment must be sufficiently high that the cost of fund diversion can be internalized on the one hand, and the monitoring cost will be covered on the one hand. This implies that there will be a community wealth threshold for the TVE at least as high as the private wealth threshold is for entrepreneurs. ${ }^{17}$ The investment by the TVE will be financed only if the community government invests an amount of the community wealth that is beyond the threshold. Thus the community government can facilitate financial contracting between the bank and the TVE when it controls a large amount of community assets.

This model indicates two counterbalancing effects in TVE governance: On the one hand, the greater the amount of physical and financial assets endowed by the community government, the lesser the external agency costs; on the other hand, community government involvement in TVE governance inflicts higher

15. The threshold wealth $\underline{w}$ can be derived from the following "incentive compatibility" condition (assuming the entrepreneur has all the bargaining power): The entrepreneur has no incentives to diver funds if and only if

$(1+a)-(1+r)(1-w) \geq \pi[(1+a)-(1+r)(1-w)]+(1-\pi) 0+b$,

which gives

$w \geq \underline{w}=[-(a-r)+b /(1-\pi)] /(1+r)$.

16. The qualitative results will remain even if we assume that the community government can divert the funds without monitoring managers.

17. The community government has incentives to monitor if

$(1+a)-(1+r)(1-W)-c \geq \pi[(1+a)-(1+r)(1-W)]$,

and the community govemment has no incentives to divert funds if

$(1+a)-(1+r)(1-W)-c \geq \pi[(1+a)-(1+r)(1-W)]+b$.

Both are satisfied if

$W \geq \underline{W}=\max \{c /(1-\pi), b /(1-\pi)\} /(1+r)-(a-r) /(1+r) \geq \underline{w}$. 
internal agency costs. And the TVE is more efficient only if the reduction of external agency costs is sufficient to compensate for the increases in internal agency costs.

Some comparative statics results also can be derived. First, when the entrepreneur's wealth is large, the external agency cost is small, thus there is unlikely any role for the community government as an intermediary. Second, the larger the monitoring costs and the greater the private benefits from diverting investment funds, the more costly for the community government's involvement. These results imply that TVEs are more likely to disappear when the government experiences an increase in monitoring costs or an increase in private benefits (say, from pursuing its political agenda) and when the entrepreneur has more wealth. Conversely, TVEs are more likely to crop up in regions where the community government is better endowed in terms of human capital, enjoys close ties with local entrepreneurs, and controls a considerable portion of the community's assets.

In the above-cited econometric work, Jin and Qian (1997) reported that the share of TVEs in rural industrial output in a province is positively related to per capita community assets at the beginning of reform in 1980, but negatively related to private financial activities (measured by the ratio of rural private financial savings to rural GDP). They also found that the share of TVEs is positively related to the state supply of credit to rural enterprises (measured by credit per rural enterprise employee). These empirical findings support the above results.

\section{Why Do TVEs Have Harder Budget Constraints Than SOEs?}

A natural question arises as to why TVEs and SOEs differ, although both are government controlled. Product market competition is often cited as a reason. It is true that TVEs are operating in competitive product markets. However, unlike SOEs in Eastern Europe and the former Soviet Union, most SOEs in China, except in a few monopoly industries, do not have much monopoly power either. Indeed, they are typically small in size and dispersed across many regions (Qian and Xu, 1993). While product market competition is necessary for achieving efficiency, it is not sufficient. We see a more fundamental difference between TVEs and SOEs in the varying degrees of hardness of budget constraints these enterprises face. Indeed, even if product markets are perfectly competitive, an inefficient firm can still survive as long as it faces soft budget constraints.

The following evidence suggests that TVEs generally have harder budget constraints than SOEs. First, TVEs have been receiving proportionally fewer loans than SOEs and they were hit badly during the retrenchment period. During the late 1980s and early 1990s, the total size of SOE industrial output was about twice that of TVEs. However, for each year between 1986 and 1992, loans to rural enterprises (mainly TVEs) accounted for only about $8 \%$ of all nonagricultural loans, while loans to SOEs accounted for about $86 \%$. Due to the retrenchment, new loans to rural enterprises fell from 15.85 billion yuan in 1988 to 12.9 billion yuan in 1989 , but new loans to SOEs increased from 128.43 
billion yuan in 1988 to 172.49 billion yuan in 1989 . Thus the share of new loans to rural enterprises in total nonagricultural areas declined from $10.2 \%$ in 1988 to $6.8 \%$ in 1989 , and the share of new loans to SOEs increased from $82.9 \%$ in 1988 to $90.5 \%$ in 1989 (Almanac of China's Finance and Banking, 1993:356). Second, TVEs are less likely to incur losses than SOEs. Total losses from all TVEs were 4.7 billion yuan in 1990 and 4.3 billion yuan in 1991 (A Statistical Survey of China, 1992:67), while the total losses from industrial SOEs alone were 34.9 billion yuan in 1990 and 36.7 billion yuan in 1991 (China Statistical Yearbook, 1994:399). Third, TVEs are more likely to reduce employment in response to a government's austerity program than SOEs. Total TVE employment fell from 48.9 million in 1988 to 47.2 million in 1989 and further to 45.9 million in 1990 , while employment in the state sector actually increased (China Statistical Yearbook, 1992). In fact, until 1993, SOEs almost never laid off workers and loss-making SOEs never went bankrupt.

This leads to an interesting question: why do TVEs have harder budget constraints than SOEs? We argue that the second basic feature of the community government (G2) may provide an answer. The soft budget constraint problem arises because of the difficulty that those (the state banks here) who bail out bad projects have in effectuating termination once investment costs are sunk (Dewatripont and Maskin, 1995). Because of differences in the structures of control rights and information allocation in the cases of TVEs and SOEs, the net benefits from refinancing projects for TVEs and SOEs differ. Thus the state bank's incentives for refinancing after sunk investments differ as well.

In order to explain how allocation of control rights affects the degree of softness of budget constraints, we follow the logic in the argument put forward by Dewatripont and Maskin (1995) and modify slightly the model in the previous section. Suppose that a project takes two periods rather than one to complete. If no funds are diverted in the first period, the project will be carried out smoothly throughout the two periods and will yield the higher return $a$. However, if funds are diverted in the first period, the fate of the project will depend on refinancing in the second period. Without refinancing, the project generates no returns and negative private benefits (reflecting the private costs of implementing a project). With refinancing, if no funds are diverted in the second period, the project generates the higher return $a$ along with some private benefits $b$ accruing to the manager (as a result of fund diversion in the first period). Otherwise the refinanced project becomes a risky one, generating the higher return $a$ with probability $\pi$ less than 1, along with a larger amount of private benefits $2 b$ accruing to the manager (as a result of repeated fund diversion in both periods). For simplicity we exclude the possibility of fund diversion by the community government that was assumed previously (including such a possibility only strengthens our results).

We assume that no monitoring is possible in the first period and that with some monitoring costs the owner of an enterprise can ensure that the manager will not divert the funds in the second period. Then it is evident that a manager will not have an incentive to divert funds in the first period if the project is unlikely to be refinanced when it stumbles. On the other hand, the manager 
will divert funds if he expects the project to be refinanced, as private benefits $b$ is positive.

Whether a project will be refinanced or not depends on the control structure of the firm and the bank. In the case of an SOE, the government controls both the enterprise and the bank and receives the entire return from refinancing; hence it intemalizes the costs of monitoring. Given the sunk investment, the incentives for refinancing are high, despite the fact that the govern $r \quad \therefore$ does not like refinancing before the first period because managers tend to behave opportunistically. This internalization of the monitoring costs by maintaining control over both an enterprise and the bank is ex post efficient, but ex ante inefficient.

In the case of a TVE, the community government controls TVEs, but not the state bank. Let us suppose that the funds are diverted in the first period and hence the project needs refinancing in the second period. By assumption, in order for refinancing to be profitable for the bank, the community government needs to monitor the manager in the second period. When controls over the enterprise and over the bank are separate, the community government needs to be motivated for monitoring managers. Consequently, in order to induce the community government to monitor, some amount of incentive rents have to be paid out of project returns to the community government. This reduces the project returns to the bank. Accordingly, from the point of view of the bank, refinancing a TVE is more expensive than refinancing an SOE. It follows that the bank is more inclined to refuse refinancing when a TVE's project stumbles in the first period. This in turn reduces the manager's incentives to divert funds in the first period.

Essentially, with TVEs, because the community government does not control banks, there is a separation of control over information (i.e., through monitoring managers) and control over funds: the community government has control over information but not funds, while banks have control over funds but not information. This implies that some rents have to be transferred from the bank to the community government, thereby reducing the bank's incentives for ex post refinancing. This in turn increases ex ante efficiency. In such a manner, this separation of power serves as a commitment device that is used to achieve harder budget constraints. ${ }^{18}$

\section{Conclusions}

We have analyzed the phenomenon of China's township-village enterprises from an organizational perspective and with a focus on governance. Unlike most of the literature on TVEs that identifies the boundaries of the firm at the individual enterprise level, we view the boundaries of the firm at the community level. We draw important parallels and highlight crucial differences in gover-

18. Although we have followed the logic of analysis by Dewatripont and Maskin (1995), our model setup and results differ from theirs. In their model, a soft budget constraint is associated with centralization of credit, and a hard budget constraint is associated with decentralization of credit. In our model, we take the state-controlled banking system as the given institutional environment and show how a soft budget constraint arises in SOEs and a hard budget constraint in TVEs because of different control rights allocation over enterprises and banks. 
nance structures between TVEs and conventional, publicly held multi-divisional corporations in the West. From this perspective, we analyze the central role that community governments play in TVE governance as an organizational response to the imperfect institutional environment of both state and market. What underlies these roles, we argue, is the fact that community govemments in rural China are appropriately empowered (G1) and constrained (G2).

Two general lessons can be drawn from China's TVE experience. First, in transition and developing economies, the ownership of firms and corporate governance should consider the institutional environments of both the state and market. The distinct feature of transition and developing economies is the underdevelopment of institutions that constrain the state and support markets. Unfortunately, in many transition and developing economies, perhaps too much faith is placed in idealized state and market institutions without enough attention paid to the reality of the existing institutional environment. In China, however, the organizational innovation of TVEs as a "community corporation" emerged and succeeded at the time when both the state and privately owned enterprises were experiencing difficulties with growth. In our analysis, TVE governance is perceived as an organizational response to imperfect institutions in China. Although this new organizational structure differs from, and appears less efficient than, those found in mature market economies, it functions better given the institutional reality. ${ }^{19}$

Second, local governments can be a driving force in economic transition and development, provided that they are both appropriately empowered and constrained. The TVE experience as a transition and development model differs considerably from those in Eastern Europe and the former Soviet Union and many other developing countries where local governments have played a much less significant role. One plausible reason may be that China's community governments have full autonomy over a range of community activities, including both government and business activities (G1). This may help explain why other transition and developing countries have not developed business organizations similar to TVEs, despite similarly imperfect institutional environments. In sum, the success of TVEs in China demonstrates that there is no standard model of transition from plan to market, nor does there exist such a model for economic development.

\section{Appendix: The Evolution of TVEs \\ Prior to 1979}

The primitive stage of TVEs can be traced back to 1958, the time of the Great Leap Forward and the inception of the commune system. Many small-scale industrial enterprises (e.g., steel mills) were set up by communes, and all of

19. The underlying "second-best" principle is quite general in studying institutions and political economy. For example, Spiller and Sampson (1994) argue that the apparently inefficient pricing schemes and regulatory structure in Jamaican telecommunications can be viewed as a second-best altemative that reflects a pragmatic response to the imperfect Jamaican government institutions in the areas of public utilities. 
them failed shortly thereafter. These failed experiments were the first attempt at rural industrialization in which community governments played an essential role.

During the nationwide agricultural mechanization drive of the early 1970 s, rural small-scale industrial enterprises rapidly re-emerged (Wong, 1991). Most of these enterprises started as agricultural machine repair shops and food processing mills, and many of them soon became subcontractors of SOEs in nearby urban areas. These community enterprises were known as "commune and brigade enterprises," the predecessor to the TVEs. The total output value of commune and brigade enterprises increased from 9.25 billion yuan in 1970 to 27.2 billion yuan in 1976, with an average annual real growth rate of $25.7 \%$ (Byrd and Lin, 1990:10). By 1978 there were about 1.5 million such enterprises with a total output value of 49.3 billion yuan (China Statistical Yearbook, 1992:389-390), of which 38.5 billion yuan was for industrial output, which accounted for $9 \%$ of the national industrial output (Ministry of Agriculture, China, 1992a:1).

1979-1993

Since 1979 when economic reform took place, the TVEs have become the most dynamic sector in the economy, especially after 1985. As the household responsibility system replaced the commune production scheme in agriculture, community government shifted their focus to rural industrialization. In 1984, with the abolishment of the commune system, the central government renamed commune and brigade enterprises as township and village enterprises. At the end of 1992, China had 48,200 townships and 806,000 villages. On average, each township with a population of about 18,000 has 8.2 township enterprises with 66 employees per enterprise, and each village with a population of about 1,000 has 1.4 village enterprises with 23 employees per enterprise (China Statistical Yearbook, 1993:15;395). Between 1978 and 1993, the share of industrial output of TVEs as a national total increased from $9 \%$ to $27 \%$ (see Table 1).

During this period the central government's attitude toward TVEs changed from tolerance to encouragement. It issued several internal documents that promoted TVEs in the 1980s, and released the public and national legal regulations on TVEs in 1990 (see Section 2). The only central govemment agency responsible for TVEs is the small "Township and Village Enterprises Bureau" under the Ministry of Agriculture. Supervision of TVEs was carried out by the county governments.

\section{Since 1994}

Several new developments concerning TVEs have emerged since 1994. One is the rise of the mixed corporate form known as "joint-stock cooperatives" (gufen hezuozhi). Under this form, shares of TVEs are sold or distributed to TVE employees and managers or community residents in the form of both "collective shares" ("one person, one vote") and conventional individual shares ("one share, one vote"). Another development is the privatization of TVEs, mainly in the form of sales of control rights to managers and employees or 
to foreign investors. After the privatization, the community government continues to play a role in rural industrialization by concentrating its attention on investment in infrastructure (e.g., power supplies, roads, and harbors), coordination and urban planning, and other conventional public works. In some cases, the community governments continue to hold a minority stake in the partially privatized former TVEs.

Another significant development is the direct election of village and township leaders by community residents. By 1995, about one-third of the villages had already formulated "village self-governing charters," more than one-half of the villages had established "village resident congresses," and more than $90 \%$ of village residents had participated in elections. It is also reported that to promote direct election in villages, China has established model villages in 63 counties, in 3,917 townships and in 82,266 villages (People's Daily, November 15, 1995).

\section{References}

A Statistical Survey of China. Various years. Beijing: China Statistical Publishing House.

Almanac of China's Finance and Banking. 1993. Beijing: China Finance Publishing House.

Byrd, William. 1990. "Entrepreneurship, Capital, and Ownership," in William Byrd and Qingsong

Lin, eds., China's Rural Industry: Structure, Development, and Reform. Oxford: Oxford University Press.

and Qingsong Lin. 1990. "China's Rural Industry: An Introduction," in William Byrd and Qingsong Lin, eds., China's Rural Industry: Structure, Development, and Reform. Oxford: Oxford University Press.

Chandler, Alfred, Jr. 1966. Strategy and Structure. New York: Doubleday.

Chang, Chun, and Yijiang Wang. 1994. "The Nature of the Township Enterprise," 19 Journal of Comparative Economics 434-452.

China Statistical Yearbook. Various years. Beijing: China Statistical Publishing House.

Dewatripont, Mathias, and Eric Maskin. 1995. "Credit and Efficiency in Centralized and Decentralized Economies, 62 Review of Economic Studies 541-555.

Grossman, Sanford, and Oliver Hart. 1986. "The Costs and Benefits of Ownership: A Theory of Vertical and Lateral Integration," 94 Journal of Political Economy 691-719.

Har, Oliver, and John Moore. 1990. "Property Rights and the Nature of the Firm," 98 Journal of Political Economy 1119-1158.

Holmstrom, Bengt. 1995. "Financing of Investment in Eastem Europe: A Theoretical Perspective," working paper, MIT.

Jin, Hehui, and Yingyi Qian. 1997. "Public vs. Private Ownership of Firms: Evidence from Rural China," working paper, Stanford University.

Kornai, Janos. 1980. Economics of Shortage. Amsterdam: North Holland.

Li, David D. 1996. "Ambiguous Property Rights in Transition Economies," 23 Journal of Comparative Economics 1-19.

Litwack, John. 1991. "Legality and Market Reform in Soviet-Type Economies," 5 Journal of Economic Perspectives 77-90.

Ma, Rong, Hansheng Wang, and Shiding Lin. 1994. Zhongguo Xiangzhen Qiye de Fazhan Lishi he Yunxing Jizhi (Development History and Operating Mechanisms of China's Township Enterprises). Beijing: Peking University Press.

McKinnon, Ronald. 1994. Gradual versus Rapid Liberalization in Sacialist Economies: Financial Policies in China and Russia Compared. ICEG Sector Studies Series No. 10. San Francisco: International Center for Economic Growth.

Ministry of Agriculture, China. 1986. Xiangzhen Qiye Tongii Ziliao 1978-85 (Township Enterprises Statistical Material 1978-85). Beijing: Department of Rural Enterprises of Ministry of Agriculture. 
Ministry of Agriculture, China. 1990. Zhonghua Renmin Gongheguo Xiangcun Jiti Suoyouzhi Qiye Tiaoli Tiaowen Shiyi (Explanations of the Regulation on Township and Village Collective Enterprises of the People's Republic of China). Beijing: China Legal Press.

1992a. Xiangzhen Qiye Tongji Ziliao, 1992 (Statistical Materials of Township Enterprises,

1992). Beijing: Department of Rural Enterprises of Ministry of Agriculture.

1992b. Zhongguo Xiangzheng Qiye Tongji Zhaiyao 1992 (A Statustical Survey of China's Township Enterprises 1992). Beijing: Department of Rural Enterprises of Ministry of Agriculture.

Naughton, Barry. 1994. "Chinese Institutional Innovation and Privatization from Below," 84 American Economic Review 266-270.

Nee, Victor. 1992. "Organizational Dynamics of Market Transition: Hybrid Forms, Property Rights and Mixed Economy in China," 37 Administrative Science Quarterly 1-27.

North, Douglass C. 1990. Institutions, Institutional Changes, and Economic Performance. Cambridge: Cambridge University Press.

Oi, Jean. 1992. "Fiscal Reform and the Economic Foundations of Local State Corporatism in China," 45 World Politics 99-126.

1994. "Rural China Take off: Incentives for Reform," manuscript, Harvard University.

Qian, Yingyi, and Barry R. Weingast 1996 "China's Transition to Markets: Market-Preserving Federalism, Chinese Style," 1 Joumal of Policy Reform 149-185. and Chenggang Xu. 1993. "Why China's Economic Reforms Differ: The M-Form Hierarchy and Entry/Expansion of the Non-State Sector," 1 Economics of Transition 135-170.

Spiller, Pablo T., and Cezley I. Sampson. 1994. "Regulation, Institutions, and Commitment: The Jamaican Telecommunications Sector," Policy Research Working Paper 1362, The World Bank.

Weitzman, Martin, and Chenggang Xu. 1994. "Chinese Township Village Enterprises as Vaguely Defined Cooperatives," 18 Journal of Comparative Economics 121-145.

Whiting, Susan. 1995. "The Micro-Foundations of Institutional Change in Reform China: Property Rights and Revenue Extraction in the Rural Industrial Sector." Ph.D. dissertation, University of Michigan.

Willamson, Oliver, 1975. Markets and Hierarchies. New York: Free Press.

Wong, Christine, 1991. "The Maoist 'Model' Reconsidered: Local Self-Reliance and its Financing of Rural Industrialization," in William Joseph, Chrstine Wong, and David Zweig, eds., New Perspectives on the Cultural Revolution. Cambridge: Harvard University Press. 1992. "Fiscal Reform and Local Industrialization," 18 Modem China 197-227.

Zhang. Gang, and Per Ronnas. 1993. "The Capital Structure of Township Enterprises," working paper, Stockholm School of Economics. 